DOI: 10.17805/trudy.2015.6.9

\title{
К 125-ЛЕТИЮ БОРИСА ПАСТЕРНАКА
}

\author{
Н. В. Захаров \\ (Московский гуманитарный университет)
}

Аннотация: В статье представлен обзор торжественного заседания, посвященного 125-летию Б. Л. Пастернака, которое прошло 10 февраля 2015 г. в Московском гуманитарном университете.

Ключевые слова: Год литературы; Московский гуманитарный университет; Русский Шекспир; Б. Л. Пастернак; обзор

\section{$125^{\text {TH }}$ ANNIVERSARY OF BORIS PASTERNAK}

\author{
N. V. Zakharov \\ (Moscow University for the Humanities)
}

\begin{abstract}
This is an overview of a commemorative event to honor the 125th anniversary of Boris Pasternak, which took place on February 10, 2015 at Moscow University for the Humanities.
\end{abstract}

Keywords: Year of Literature; Moscow University for the Humanities; Russian Shakespeare; B. L. Pasternak; overview

10 февраля 2015 г. в Московском гуманитарном университете состоялось открытие Года литературы. Ученые МосГУ совместно с Шекспировской комиссией при Научном совете «История мировой культуры» РАН провели торжественное заседание, посвященное 125 -летию великого русского писателя, поэта и переводчика Бориса Леонидовича Пастернака.

С приветственным словом выступил заместитель председателя Оргкомитета круглого стола - проректор Московского гуманитарного университета по научной и издательской работе - директор Института фундаментальных и прикладных исследований МосГУ, доктор философских наук, профессор, заслуженный деятель науки Российской Федерации, вице-президент Международной академии наук (IAS) B. А. Луков. Он отметил выдающуюся роль Б. Л. Пастернака в приближении творчества Шекспира к русскому читателю, значения его переводов восьми пьес в развитии такого культурного феномена, как «Русский Шекспир».

Говоря о традиции проведения литературных форумов в универси- 
тете Вал. А. Луков напомнил о том, что в разные годы здесь выступали Александр Твардовский, Валентин Катаев, практически все поэты времен оттепели - Андрей Вознесенский, Роберт Рождественский, Евгений Евтушенко, Белла Ахмадулина, барды Булат Окуджава, Владимир Высоцкий и мн. др. Традиция проведения литературных праздников в университете получила особенно большое развитие в последние десять лет. Вкладом МосГУ в современный литературный процесс профессор Луков назвал конкурс на соискание Бунинской премии, которая была учреждена рядом российских негосударственных вузов в 2004 г. (председатель Попечительского совета премии - ректор МосГУ профессор И. М. Ильинский). Многие годы жюри премии возглавлял заслуженный деятель культуры С.И. Бэлза; сегодня его возглавляет видный отечественный литературовед профессор Литературного института им. А. М. Горького Б. Н. Тарасов.

Ежегодно премии вручаются 22 октября в день рождения великого русского писателя, нобелевского лауреата Ивана Алексеевича Бунина. За прошедшие годы проведены конкурсы лучших произведений в прозе, поэзии, мемуаристке, публицистике, художественном переводе. Экспертизу прошли около 900 литературных произведений. Лауреатами Бунинской премии в 2005-2013 гг. стали 65 авторов. Среди лауреатов Андрей Битов, Лариса Васильева, Глеб Горбовский, Даниил Гранин, Николай Добронравов, Борис Евсеев, Сергей Есин, Фазиль Искандер, Александр Кабаков, Тимур Кибиров, переводчик Шекспира Григорий Кружков, Инна Лиснянская, Виктор Лихоносов, Владимир Личутин, Людмила Петрушевская, Захар Прилепин, Александр Проханов и другие видные мастера художественного слова.

Далее Вал. А. Луков представил присутствующих на круглом столе членов Шекспировской комиссии РАН, работающих в МосГУ: директора Центра теории и истории культуры Института фундаментальных и прикладных исследований МосГУ, ученого секретаря Шекспировской комиссии РАН, доктора философии (PhD), кандидата филологических наук, академика Международной академии наук (IAS) - председателя оргкомитета круглого стола Н. В. Захарова; заместителя директора Центра теории и истории культуры ИФПИ МосГУ, члена-корреспондента Международной академии наук (IAS), кандидата филологических наук В. С. Макарова; доцента кафедры культуры и искусства Московского гуманитарного университета, режиссёра театра-студии «Горизонт» Московского городского дома учителя, драматурга В. Р. Поплавского.

В своем коротком выступлении Н. В. Захаров отметил особую роль работы над переводами пьес Шекспира в творческой эволюции Пастернака - самобытного художника и автора всемирно известного романа «Доктор Живаго». Пастернаковский подход к тому же «Гамлету» автобио- 
графичен, как во многом автобиографичен портрет героя Юрия Живаго. В стихотворении «Гамлет» отразилась трагическая судьба не только Принца Датского и героя романа, но и хождение по мукам самого русского поэта. Как и для Пушкина, Шекспир стал для Пастернака мерилом понимания жизни мирской и духовной. Отдельной темой для исследования может стать заочный творческий полилог «Священное писание - Шекспир Пушкин - Пастернак».

Подводя итоги прошлого шекспировского года, Н. В. Захаров отметил, что имя Пастернака постоянно звучало на многочисленных научных мероприятиях, которые проводила Шекспировская комиссия. Так, в рамках юбилейной XXV Международной научной конференции «Шекспировские чтения 2014» совместно с Всероссийской государственной библиотекой иностранной литературы им. М. И. Рудомино была организована секция «Шекспир и Пастернак». На ней прозвучали доклады, посвященные конгениальной рецепции Шекспира в творчестве и переводах Пастернака: «K реконструкции содержания утраченных статей Б. Л. Пастернака о Шекспире» Е. В. Пастернак, «„Гамлет“ и „Отелло“ в творчестве Пастернака: второе рождение» А. Ю. Сергеевой-Клятис, «Трагическое у позднего Пастернака» Е. Б. Рашковского, «Шекспир, Пастернак, Шаламов: новые материалы» А.П. Гавриловой и др.

Выступление В. Р. Поплавского было посвящено анализу концепций русских переводов шекспировских пьес. Интересным наблюдением практикующего переводчика и исследователя теории перевода стала мысль о том, что если бы отечественная школа перевода последовала примеру А. С. Пушкина, который блестяще перевел первую сцену комедии «Мера за меру» (январь - сентябрь 1833 г.), то уже в XIX веке у нас были бы совершенные художественные тексты Шекспира на русском языке. Ведь в ту пору большинство переводов из Шекспира было выполнены зачастую посредственными поэтами, и только в XX веке за них взялись настоящие состоявшиеся поэты: М. А. Кузмин, М. Л. Лозинский, В. В. Левик, А. Д. Радлова, С. Я. Маршак и, конечно же, сам Б. Л. Пастернак. Именно в творчестве мастеров перевода сочетается необходимая точность с поэтической свободой и естественностью русской речи, такая естественная для Пушкина.

За выступлением В. Р. Поплавского последовала премьера литературно-драматической композиции из произведений Уильяма Шекспира в переводе Бориса Пастернака «Грехи поэта выправит игра» в исполнении студентов актерского курса МосГУ совместно с артистами театра-студии «Горизонт» Московского городского дома учителя. Спектакль вызвал живую реакцию и массу положительных эмоций у зрителей. В его обсуждении приняли участие декан факультета культуры и искусства МосГУ, заведующая кафедрой философии, культурологии и поли- 
тологии МосГУ, академик Международной академии наук (IAS), доктор философских наук, доктор культурологии, профессор А. В. Костина, художественный руководитель любительского Театрана французском языке (Théâtre de la langue française) И. Л. Нагле, директор Московского культурологического лицея № 1310 А. П. Вдовин, кандидат филологических наук, доцент Российского государственного гуманитарного университета Г. А. Сокур, поэт-переводчик, заместитель заведующего отделом Государственного музея изобразительных искусств им. А. С. Пушкина «Учебный художественный музей им. И. В. Цветаева» А. Н. Баранов, актриса Александра Глушенкова, ученые из российских высших учебных заведений и научных центров, преподаватели, аспиранты и студенты МосГУ, учащиеся Московского культурологического лицея № 1310 и др.

В завершение круглого стола состоялось презентация новых книг из серии «Великие трагедии Шекспира в русских переводах» (издательство «ПРОЗАиК», 2014).

Захаров Николай Владимирович - кандидат филологических наук, доктор философии (PhD), директор Центра теории и истории культуры Института фундаментальных и прикладных исследований Московского гуманитарного университета, ученый секретарь Шекспировской комиссии Российской академии наук. Адрес: 111395, Россия, г. Москва, ул. Юности, д. 5, корп. 6. Тел.: +7 (499) 374-75-95. Эл. адрес: nikoltine@yandex.ru

Zakharov Nikolay Vladimirovich, Candidate of Philology, PhD, Director, Center for Theory and History of Culture, Institute of Fundamental and Applied Studies, Moscow University for the Humanities; Academic Secretary, Shakespeare Committee, Russian Academy of Sciences. Postal address: Bldg. 6, 5 Yunosti St., 111395 Moscow, Russian Federation. Tel. +7 (499) 374-75-95. E-mail: nikoltine@yandex.ru 